\title{
iTRAQ-based quantitative proteomic analysis of the anti-apoptotic effect of hyperin, which is mediated by Mcl-1 and Bid, in $\mathrm{H}_{2} \mathrm{O}_{2}$-injured EA.hy926 cells
}

\author{
XIAO-XIA LIU ${ }^{1 *}$, LI TANG $^{2 *}$, RUI GE ${ }^{2}$, JIAN-KUAN LI $^{2}$, YA KANG ${ }^{1}$, \\ MEI-XIA ZHU ${ }^{1}$, QING-SHAN LI $^{2}$ and XU-LIANG HAO ${ }^{1}$ \\ ${ }^{1}$ Shanxi Institute of Traditional Chinese Medicine, Taiyuan, Shanxi 030012; \\ ${ }^{2}$ School of Pharmaceutical Science, Shanxi Medical University, Taiyuan, Shanxi 030001, P.R. China
}

Received May 19, 2015; Accepted February 16, 2016

DOI: $10.3892 / \mathrm{ijmm} .2016 .2510$

\begin{abstract}
Endothelial injury has been implicated in the pathogenesis of many cardiovascular diseases, including thrombotic disorders. Hyperin (quercetin-3-O-galactoside), a flavonoid compound and major bioactive component of the medicinal herb Apocynum venetum L., is commonly used to prevent endothelium dysfunction. However, its mode of action remains unclear. To the best of our knowledge, we have for the first time investigated the protective effect hyperin exerts against $\mathrm{H}_{2} \mathrm{O}_{2}$-induced injury in human endothelium-derived EA.hy 926 cells using isobaric tags for relative and absolute quantitation (iTRAQ)-based quantitative proteomic analysis. The results showed that $\mathrm{H}_{2} \mathrm{O}_{2}$ exposure induced alterations in the expression of 250 proteins in the cells. We noted that the expression of 52 proteins associated with processes such as cell apoptosis, cell cycle and cytoskeleton organization, was restored by hyperin treatment. Of the proteins differentially regulated following $\mathrm{H}_{2} \mathrm{O}_{2}$ stress, the anti-apoptotic protein, myeloid cell leukemia-1 (Mcl-1), and the pro-apoptotic protein, BH3-interacting domain death agonist (Bid), exhibited marked changes in expression. Hyperin increased Mcl-1 expression and decreased that of Bid in a dose-dependent manner. In addition, flow cytometric analysis and western blot analysis of the apoptosis-related proteins, truncated BID (tBid), cleaved caspase-3, cleaved caspase-9, Fas, FasL and caspase-8, demonstrated that the rate of apoptosis and the pro-apoptotic
\end{abstract}

Correspondence to: Dr Xu-Liang Hao, Shanxi Institute of Traditional Chinese Medicine, 46 Bingzhou Road West, Taiyuan, Shanxi 030012, P.R. China

E-mail: hxliang-01@163.com

Dr Qing-Shan Li, School of Pharmaceutical Science, Shanxi Medical University, 56 Xinjian South Road, Taiyuan, Shanxi 030001, P.R. China E-mail: sxlqs2012@163.com

${ }^{*}$ Contributed equally

Key words: hyperin, EA.hy926 cells, iTRAQ, Bid, myeloid cell leukemia-1, anti-apoptotic protein levels were decreased by hyperin pre-treatment. In the present study we demonstrate that hyperin effectively prevents $\mathrm{H}_{2} \mathrm{O}_{2}$-induced cell injury by regulating the Mcl-1and Bid-mediated anti-apoptotic mechanism, suggesting that hyperin is a potential candidate for use in the treatment of thrombotic diseases.

\section{Introduction}

Endothelial dysfunction has been implicated in the pathogenesis of many cardiovascular diseases, including thrombotic disorders $(1,2)$. Oxidative stress plays an important role in endothelial dysfunction, which results in apoptosis of endothelial cells, destruction of vascular barrier integrity, increased endothelial permeability, platelet aggregation and generation of cytokines, consequently promoting thrombotic diseases $(3,4)$. Thus, protecting endothelial cells against apoptosis is likely to be a beneficial intervention strategy for thrombotic diseases.

Flavonoids are polyphenolic compounds that are widespread in many plants, and exert various biochemical and pharmacological effects (5). Hyperin (quercetin-3-O-galactoside) is considered the major bioactive flavonoid component in the medicinal herb, Apocynum venetum $\mathrm{L}$., which has been used extensively for the treatment of hypertension in Chinese medicine. Previous studeis have suggested that hyperin plays various biological roles, including anti-inflammatory $(6,7)$, cytoprotective (8) and anti-ischemic roles (9). Our previous study revealed that hyperin protects cells from $\mathrm{H}_{2} \mathrm{O}_{2}$-induced injury (10). However, its underlying mode of action has not yet been elucidated.

Isobaric tags for relative and absolute quantitation (iTRAQ) (11) is a method used to screen the entire proteome within the detectable dynamic range for qualitative and quantitative differences in cell protein expression before and after drug treatment. Compared to other proteomic technologies, it has many advantages, including a high throughput and compatibility with various sample types. The technique has been shown to be suitable for the identification of lower abundance proteins such as transcription factors (12), which makes it applicable for investigating molecular mechanisms and discovering drug targets. 
In the present study, iTRAQ-based proteomic analysis was applied to investigate the effect of hyperin against $\mathrm{H}_{2} \mathrm{O}_{2}$-induced injury in human endothelium-derived EA.hy926 cells, and to elucidate the potential protective mechanism of hyperin in oxidative stress-induced injury.

\section{Materials and methods}

Chemicals and reagents. Hyperin was purchased from the National Institutes for Food and Drug Control (Beijing, China); its chemical structure is shown in Fig. 1. Dulbecco's modified Eagle's medium (DMEM) and fetal bovine serum (FBS) were purchased from Gibco (Grand Island, NY, USA). iTRAQ reagent was obtained from Applied Biosystems Life Technologies (Foster City, CA, USA). Antibodies against BH3-interacting domain death agonist (Bid; BS1819), myeloid cell leukemia-1 (Mcl-1; BS1220), $\beta$-actin (AP0060), Fas (BS6430) and FasL (BS1122) were obtained from Bioworld Technology, Inc., (Nanjing, China). Antibody against truncated tBID (tBID; ab10640) was purchased from Abcam (Cambridge, UK). Antibodies against caspase-3 (\#9664), caspase-8 (\#8592) and caspase-9 (\#9509) were purchased from Cell Signaling Technology, Inc. (Beverly, MA, USA). Other reagents were obtained from Sigma-Aldrich (St. Louis, MO, USA). $\mathrm{H}_{2} \mathrm{O}_{2}$ was freshly prepared for each experiment from a $3 \%$ stock solution.

Cell culture and treatments. EA.hy926 cells were purchased from the Cell Bank of the Chinese Academy of Sciences (Beijing, China) and were cultured in DMEM supplemented with heat-inactivated FBS (10\%), $100 \mathrm{U} / \mathrm{ml}$ penicillin, and $100 \mathrm{~g} / \mathrm{ml}$ streptomycin. The cells were incubated in a humidified incubator aerated with $5 \% \mathrm{CO}_{2}$ at $37^{\circ} \mathrm{C}$. Hyperin was dissolved in dimethyl sulfoxide (DMSO), and the DMSO content in all groups was $<0.1 \%$. Prior to treatment, the cells were incubated with serum-free medium for $24 \mathrm{~h}$ and randomly assigned to three groups: a 'control group', an ' $\mathrm{H}_{2} \mathrm{O}_{2}$-exposed group', and a 'hyperin-treated group'. The cells in the hyperin group were treated with designated concentrations of hyperin for $24 \mathrm{~h}$ prior to $200 \mu \mathrm{mol} / 1 \mathrm{H}_{2} \mathrm{O}_{2}$ exposure for $4 \mathrm{~h}$ in fresh medium.

Cell viability assay. Cell viability was evaluated using 3-(4,5-dimethylthiazol-2-yl)-2,5-diphenyltetrazolium bromide (MTT) assay. Briefly, EA.hy926 cells (in logarithmic phase) were seeded into 96-well plates $\left(1 \times 10^{4}\right.$ cells/well) and cultured for $24 \mathrm{~h}$. The medium was then replaced with fresh medium for the different treatments. Each concentration of reagent was added to the culture fluid of six parallel wells and a blank well was used as a control. Subsequently, $10 \mu 1$ of $5 \mathrm{mg} / \mathrm{ml}$ MTT in phosphate-buffered saline (PBS) was added to each well and the cells were further incubated for $4 \mathrm{~h}$. The culture medium was then carefully removed and DMSO (100 $\mu \mathrm{l} /$ well) was added to dissolve the formazan precipitate. The plates were shaken for $10 \mathrm{~min}$. Optical density was read at $570 \mathrm{~nm}(490 \mathrm{~nm}$ as reference) on a universal microplate reader (Model 680; Bio-Rad Laboratories, Inc., Hercules, CA, USA). The viability of the EA.hy926 cells in each well was expressed as a percentage of the viable control cells.

Protein extraction and labeling with iTRAQ reagents. The cells of each experimental group were collected by centrifugation

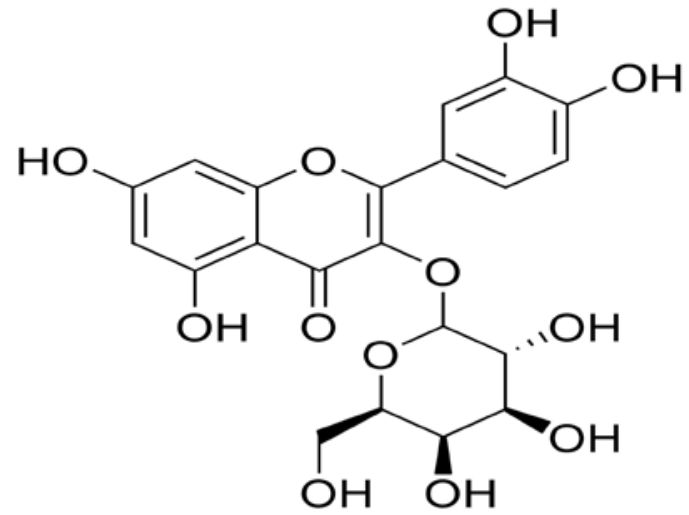

Figure 1. Chemical structure of hyperin.

(138 x g for $5 \mathrm{~min}$ ) and washed twice with PBS. Protein extracts were prepared using lysis buffer $(8 \mathrm{~mol} / 1$ urea, $30 \mathrm{mmol} / \mathrm{l}$ HEPES, 1 mmol/1 PMSF, 2 mmol/l EDTA, 10 mmol/1 DTT). The protein concentration was estimated using a Bradford assay. iTRAQ labeling was performed according to the manufacturer's instructions (Applied Biosystems/MDS SCIEX, Toronto, ON, Canada). Briefly, $100 \mu \mathrm{g}$ of each protein sample was reduced, alkylated and subjected to trypsin hydrolysis. Each sample was labeled separately with the isobaric tags as follows: control group (114 tags), $\mathrm{H}_{2} \mathrm{O}_{2}$ group (115 tags), and hyperin group (116 tags). All labeled peptides were pooled and dried in a SpeedVac (Thermo Fisher Scientific, Waltham, MA, USA.

High-pH reversed-phase chromatography. The combined iTRAQ-labeled samples were dissolved in $200 \mu \mathrm{l}$ buffer A [25\% acetonitrile (ACN), $10 \mathrm{mmol} / 1 \mathrm{KH}_{2} \mathrm{PO}_{4}, \mathrm{pH} 3.0$, with phosphoric acid]. The proteins were separated on a Luna SCX column (4.6x250 mm, 100- $\AA$ pore size; Phenomenex, Inc., Torrance, CA, USA) with buffers A and B (buffer b: $25 \%$ $\mathrm{ACN}, 2 \mathrm{~mol} \mathrm{KCl}, 10 \mathrm{mmol} / 1 \mathrm{KH}_{2} \mathrm{PO}_{4}$, $\mathrm{pH} 3.0$, with phosphoric acid) at a flow rate of $400 \mathrm{nl} / \mathrm{min}$. A solvent gradient system was used as follows: 0-35 $\mathrm{min}, 0 \% \mathrm{~B} ; 35-36 \mathrm{~min}, 0-5 \% \mathrm{~B}$; 36-56 min, 5-30\% B; 56-61 min, 30-50\% B; 61-66 min, 50\% B; $66-71 \mathrm{~min}, 50-100 \% \mathrm{~B}$; 71-81 $\mathrm{min}, 100 \% \mathrm{~B}$. Elution was monitored by measuring absorbance at $214 \mathrm{~nm}$ and fractions were collected every $1 \mathrm{~min}$. The collected eluents were lyophilized to powder and resuspended in $0.1 \%(\mathrm{v} / \mathrm{v})$ trifluoroacetic acid (TFA; $40 \mu \mathrm{l}$ ) for further desalting and concentration using a Strata-X C18 cartridge (Phenomenex, Torrance, CA, USA). The desalted samples were lyophilized to powder.

Liquid chromatography-tandem mass spectrometry (LC$M S / M S)$. In this study, iTRAQ-labeled samples were redissolved in $6 \mu$ leluent buffer A [0.1\% formic acid (FA) in water, v/v]. Each of the fractions was analyzed three times using a Q-Exactive Orbitrap mass spectrometer (Thermo Fisher Scientific). A flow rate of $400 \mathrm{nl} / \mathrm{min}$ was used for protein separation on a C18 capillary column (Michrom Bioresources, Inc., Auburn, CA, USA). A solvent gradient system was used: 0-10 min, 5\% B (0.1\% FA in ACN); 10-40 min, 5-30\% B; 40-45 min, 30-60\% B; 45-48 min, 60-80\% B; 48-55 min, 80\% B; $55-58 \mathrm{~min}, 80-5 \% \mathrm{~B}$; 58-65 min, 5\% B. A full MS scan (350-2,000 m/z range) was acquired in the Orbitrap at a mass resolution of 70,000. 
A maximum of 10 precursors per cycle were then chosen for fragmentation by high-energy collision dissociation (HCD) in the C-trap in linear trap quadrupole with an isolation width of $3.0 \mathrm{~m} / \mathrm{z}$. Precursor ion activation was performed with an isolation width of $2.5 \mathrm{Da}$. The ion transfer tube temperature and spray voltage were $320^{\circ} \mathrm{C}$ and $1.8 \mathrm{kV}$, respectively.

Protein analysis. For protein identification, MS/MS spectra were analyzed using Proteome Discoverer software v. 1.3 (PD; Thermo Fisher Scientific). The precursor ion mass range was set at 350-6,000 Da. The minimum number of peaks in a spectrum was set to 10 , and the threshold for the $\mathrm{S} / \mathrm{N}$ ratio was set to 1.5. Next, the MS spectra were searched using Mascot 2.3.0 (Matrix Science, London, UK) with precursor mass tolerance at $15 \mathrm{ppm}$, fragment ion mass tolerance at $20 \mathrm{mmu}$, trypsin enzyme with 1 miscleavage, methyl methanethiosulfonate of cysteine and iTRAQ 8-plex of lysine and the $\mathrm{NH}_{2}$-terminus as fixed modifications, and deamidation of asparagine and glutamine, oxidation of methionine and iTRAQ 8-plex of tyrosine as variable modifications. Protein identifications were accepted at $95 \%$ or higher probability and contained at least two identified peptides with a false discovery rate (FDR) $<1 \%$. The peptides were quantified using PD software. Tagged samples were normalized by comparing median protein ratios for the reference channel. Protein quantitative ratios were calculated from the median of all peptide ratios. The proteins with a relative expression of $>1.2$ or $<0.8$, and with $\mathrm{P}<0.05$ to ensure up- and downregulation authenticity, were chosen for further analysis. Protein sequences and functional information were retrieved from the UniProt databases (http://www.uniprot.org/). For further analysis, functional annotation analysis of altered proteins was carried out using DAVID annotation software (http://david.abcc.ncifcrf.gov/) and the KEGG database (http:// www.genome.jp/kegg/) by importing GenInfo (GI) numbers.

Western blot analysis. Following treatment with various concentrations of hyperin and/or $\mathrm{H}_{2} \mathrm{O}_{2}$ as described above, the EA.hy926 cells were harvested and washed with PBS. Protein extracts were prepared with RIPA buffer (Beyotime Institute of Biotechnology, Shanghai, China). Protein concentration was estimated using a bicinchoninic acid (BCA) protein assay kit (Sangon Biotech, Shanghai, China). For western blot analysis, equal amounts of protein $(50 \mu \mathrm{g})$ were separated on $12 \%$ sodium dodecyl (SDS)-polyacrylamide gels and electrotransferred onto nitrocellulose membranes (PALL Gelman Laboratory, Ann Arbor, MI, USA) that were blocked in $5 \%$ non-fat milk. The membranes were incubated overnight at $4^{\circ} \mathrm{C}$ with primary antibodies. After three washes with Tris-buffered saline containing $0.05 \%$ Tween-20 (TBS-T), the membranes were incubated for $1 \mathrm{~h}$ with horseradish peroxidase (HRP)-conjugated goat anti-rabbit IgG secondary antibody at room temperature. The bands were visualized using an ECL detection kit (CoWin Biotech, Beijing, China). Quantification of the bands was performed by densitometric analysis using the Adobe Photoshop 7.0.1 software (Adobe Systems, Inc., San Jose, CA, USA).

Flow cytometric analysis. Quantitative detection of apoptotic cells and analysis of cell cycle distribution in the cultures were undertaken using flow cytometry. The EA.hy926 cells treated with different concentrations of hyperin and/or exposed to $200 \mu \mathrm{mol} / 1 \mathrm{H}_{2} \mathrm{O}_{2}$ were collected by centrifugation ( $138 \mathrm{x} \mathrm{g}$ for $5 \mathrm{~min})$ and cell density was adjusted to $1 \times 10^{5}$ cells $/ \mathrm{ml}$. The cells were washed twice with cold PBS and centrifuged (138 x g for $5 \mathrm{~min})$. The pellets were fixed overnight in pre-cooled $70 \%$ (v/v) ethanol at $4^{\circ} \mathrm{C}$, and then washed with cold PBS. The cells were suspended in $1 \mathrm{ml}$ of propidium iodide solution $(20 \mathrm{mg} /$ ml) supplemented with $0.25 \mathrm{mg} / \mathrm{ml}$ RNase A and $0.1 \%(\mathrm{v} / \mathrm{v})$ Triton X-100, and incubated on ice for $30 \mathrm{~min}$ in the dark. The samples were analyzed with a FACSCalibur flow cytometer (BD Biosciences, San Jose, CA, USA).

Statistical analysis. Each experiment was performed at least 3 times. All data are expressed as the means \pm SD. Statistical analysis was performed using a Student's t-test and SPSS 18.0 software (SPSS Inc., Chicago, IL, USA). A P-value $<0.05$ was considered to indicate a statistically significant difference.

\section{Results}

Hyperin protects EA.hy926 cells against $\mathrm{H}_{2} \mathrm{O}_{2}$-induced cell death. We assessed whether hyperin protects EA.hy926 cells against the effect of $\mathrm{H}_{2} \mathrm{O}_{2}$ by MTT assay. No obvious cytotoxicity in untreated cells was noted, nor was obvious cytoxicity noted in cells treated with hyperin at concentrations in the range of 2.5-80 $\mu \mathrm{mol} / 1$ (Fig. 2A). We also noted that hyperin exerted a protective effect on $\mathrm{H}_{2} \mathrm{O}_{2}$-injured cells in a dose-dependent manner (Fig. 2B). When the cells were treated with $20 \mu \mathrm{mol} / 1$ hyperin, cell viability was restored to $98 \%$. Therefore, this concentration was selected for subsequent proteomic analysis.

Hyperin protects EA.hy926 cells against $\mathrm{H}_{2} \mathrm{O}_{2}$-induced changes in the proteome. A total of 3,640 proteins were identified using iTRAQ, of which 250 were altered by $\mathrm{H}_{2} \mathrm{O}_{2}$ (data not shown); the 250 proteins were functionally classified into various relevant categories such as transition metal ion-binding, zinc ion-binding and transferase activity, which are mainly involved in regulating cellular component organization, growth, cytoskeleton organization, and response to stimulus, using the NCBI online database and DAVID software platform; the most significantly up- and downregulated proteins are shown in Fig. 3. Further analysis of the pathways and networks revealed that the regulated proteins were mainly involved in apoptosis, inositol phosphate metabolism and vitamin B6 metabolism.

Following treatment with hyperin, of the 250 proteins that exhibited altered expression upon $\mathrm{H}_{2} \mathrm{O}_{2}$ exposure, 52 revealed a tendency towards restoration of the expression levels (Table I). Compared with the $\mathrm{H}_{2} \mathrm{O}_{2}$ group, 28 proteins were downregulated and 24 were upregulated. These proteins were associated with apoptosis, cell cycle and cytoskeleton organization.

Bid and Mcl-1 protein expression. An examination of Bid and Mcl-1 expression after the iTRAQ experiment demonstrated marked changes. Therefore, the results were validated by western blot analysis, as shown in Fig. 4. Compared with the $\mathrm{H}_{2} \mathrm{O}_{2}$-exposed group, Bid expression in the hyperin-treated groups was significantly decreased, while Mcl-1 expression was significantly increased. In both cases, the effect was dose-dependent. The results were in agreement with those of the proteomics analysis. 
Table I. List of differentially expressed proteins.

\begin{tabular}{|c|c|c|c|c|c|}
\hline Accession $^{\mathrm{a}}$ & Description & $\mathrm{MW}[\mathrm{kDa}]^{\mathrm{b}}$ & Calc. $\mathrm{pI}^{\mathrm{c}}$ & $115 / 114^{\mathrm{d}}$ & $116 / 115^{\mathrm{e}}$ \\
\hline Q5TZA2 & Rootletin & 228.4 & 5.5 & 4.464 & 0.244 \\
\hline P68402 & Platelet-activating factor acetylhydrolase IB subunit $\beta$ & 25.6 & 5.92 & 1.767 & 0.610 \\
\hline P33981 & Dual specificity protein kinase TTK & 97 & 8.16 & 1.733 & 0.647 \\
\hline Q6NSJ5 & Leucine-rich repeat-containing protein $8 \mathrm{E}$ & 90.2 & 6.96 & 1.653 & 0.555 \\
\hline O60518 & Ran-binding protein 6 & 124.6 & 5.01 & 1.639 & 0.603 \\
\hline Q6PJG6 & BRCA1-associated ATM activator 1 & 88.1 & 5.27 & 1.462 & 0.801 \\
\hline P55957 & BH3-interacting domain death agonist & 22 & 5.44 & 1.416 & 0.691 \\
\hline Q9BVK2 & $\begin{array}{l}\text { Probable dolichyl pyrophosphate } \\
\text { Glc1Man9GlcNAc2 } \alpha \text {-1,3-glucosyltransferase }\end{array}$ & 60 & 9.14 & 1.416 & 0.691 \\
\hline Q8IUC8 & Polypeptide N-acetylgalactosaminyltransferase 13 & 64 & 6.83 & 1.385 & 0.791 \\
\hline P02795 & Metallothionein-2 & 6 & 7.83 & 1.361 & 0.685 \\
\hline P04732 & Metallothionein-1E & 6 & 7.96 & 1.294 & 0.798 \\
\hline Q71U36 & Tubulin $\alpha-1 \mathrm{~A}$ chain & 50.1 & 5.06 & 1.290 & 0.654 \\
\hline P62328 & Thymosin $\beta-4$ & 5 & 5.06 & 1.271 & 0.780 \\
\hline P51858 & Hepatoma-derived growth factor & 26.8 & 4.73 & 1.263 & 0.817 \\
\hline P20962 & Parathymosin & 11.5 & 4.16 & 1.261 & 0.736 \\
\hline P14174 & Macrophage migration inhibitory factor & 12.5 & 7.88 & 1.241 & 0.808 \\
\hline P23528 & Cofilin-1 & 18.5 & 8.09 & 1.236 & 0.790 \\
\hline Q92688 & Acidic leucine-rich nuclear phosphoprotein 32 family member B & 28.8 & 4.06 & 1.232 & 0.810 \\
\hline O60232 & Sjoegren syndrome/scleroderma autoantigen 1 & 21.5 & 5.24 & 1.230 & 0.717 \\
\hline Q3MJ13 & WD repeat-containing protein 72 & 123.3 & 6.67 & 1.230 & 0.821 \\
\hline Q3YEC7 & Rab-like protein 6 & 79.5 & 5.22 & 1.230 & 0.783 \\
\hline P39687 & Acidic leucine-rich nuclear phosphoprotein 32 family member A & 28.6 & 4.09 & 1.220 & 0.768 \\
\hline Q00535 & Cyclin-dependent kinase 5 & 33.3 & 7.66 & 1.218 & 0.755 \\
\hline Q15147 & 1-Phosphatidylinositol 4,5-bisphosphate phosphodiesterase $\beta$-4 & 134.4 & 6.9 & 1.217 & 0.729 \\
\hline P58546 & Myotrophin & 12.9 & 5.52 & 1.209 & 0.769 \\
\hline Q8NCW5 & NAD(P)H-hydrate epimerase & 31.7 & 7.66 & 1.206 & 0.807 \\
\hline P00338 & L-lactate dehydrogenase A chain & 36.7 & 8.27 & 1.202 & 0.798 \\
\hline O43318 & Mitogen-activated protein kinase kinase kinase 7 & 67.2 & 7.11 & 0.833 & 1.244 \\
\hline Q9H6Y7 & E3 ubiquitin-protein ligase RNF167 & 38.3 & 5.63 & 0.824 & 1.233 \\
\hline Q04756 & Hepatocyte growth factor activator & 70.6 & 7.24 & 0.820 & 1.284 \\
\hline O00255 & Menin & 68 & 6.55 & 0.811 & 1.243 \\
\hline Q9UP83 & Conserved oligomeric Golgi complex subunit 5 & 92.7 & 6.6 & 0.806 & 1.224 \\
\hline Q8IWE4 & DCN1-like protein 3 & 34.3 & 5.12 & 0.796 & 1.280 \\
\hline Q9UBR2 & Cathepsin Z & 33.8 & 7.11 & 0.794 & 1.219 \\
\hline P0CG39 & POTE ankyrin domain family member $\mathbf{J}$ & 117.3 & 5.97 & 0.783 & 1.311 \\
\hline Q9Y676 & $28 \mathrm{~S}$ ribosomal protein $\mathrm{S} 18 \mathrm{~b}$, mitochondrial & 29.4 & 9.38 & 0.779 & 1.259 \\
\hline Q9UMR5 & Lysosomal thioesterase PPT2 & 34.2 & 6.33 & 0.769 & 1.227 \\
\hline Q9BT40 & Inositol polyphosphate 5-phosphatase $\mathrm{K}$ & 51.1 & 6.54 & 0.747 & 1.200 \\
\hline P42356 & Phosphatidylinositol 4-kinase $\alpha$ & 231.2 & 6.87 & 0.733 & 1.404 \\
\hline P39210 & Protein Mpv17 & 19.7 & 9.47 & 0.730 & 1.201 \\
\hline Q9H330 & Transmembrane protein 245 & 100.9 & 8.87 & 0.713 & 1.369 \\
\hline Q68CQ4 & Digestive organ expansion factor homolog & 37.3 & 5.66 & 0.705 & 1.234 \\
\hline Q9P2K3 & REST corepressor 3 & 87 & 5.88 & 0.692 & 1.428 \\
\hline Q6PJF5 & Inactive rhomboid protein 2 & 55.5 & 8.27 & 0.676 & 1.349 \\
\hline Q8NF91 & Nesprin-1 & 96.6 & 8.82 & 0.657 & 1.522 \\
\hline Q9UHW9 & Solute carrier family 12 member 6 & 1010.5 & 5.53 & 0.611 & 1.366 \\
\hline Q63HN8 & E3 ubiquitin-protein ligase RNF213 & 127.5 & 7.08 & 0.604 & 1.515 \\
\hline Q86UB9 & Transmembrane protein 135 & 591 & 6.48 & 0.587 & 1.958 \\
\hline Q92560 & Ubiquitin carboxyl-terminal hydrolase BAP1 & 52.3 & 9.45 & 0.453 & 1.938 \\
\hline Q86WA8 & Lon protease homolog 2 , peroxisomal & 80.3 & 6.84 & 0.442 & 1.352 \\
\hline Q07820 & Induced myeloid leukemia cell differentiation protein Mcl-1 & 94.6 & 7.3 & 0.408 & 2.215 \\
\hline Q8TE02 & Elongator complex protein 5 & 34.8 & 4.97 & 0.772 & 1.217 \\
\hline
\end{tabular}

Differentially expressed proteins. ${ }^{a}$ Swiss-Prot accession number; ${ }^{b} \mathrm{MW}$, molecular weight of the matched protein in $\mathrm{kDa}$; ${ }^{\mathrm{c}} \mathrm{pI}$, isoelectric point of

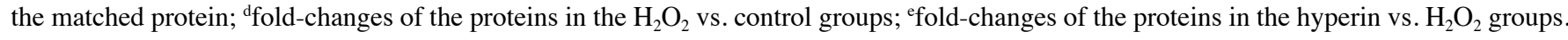



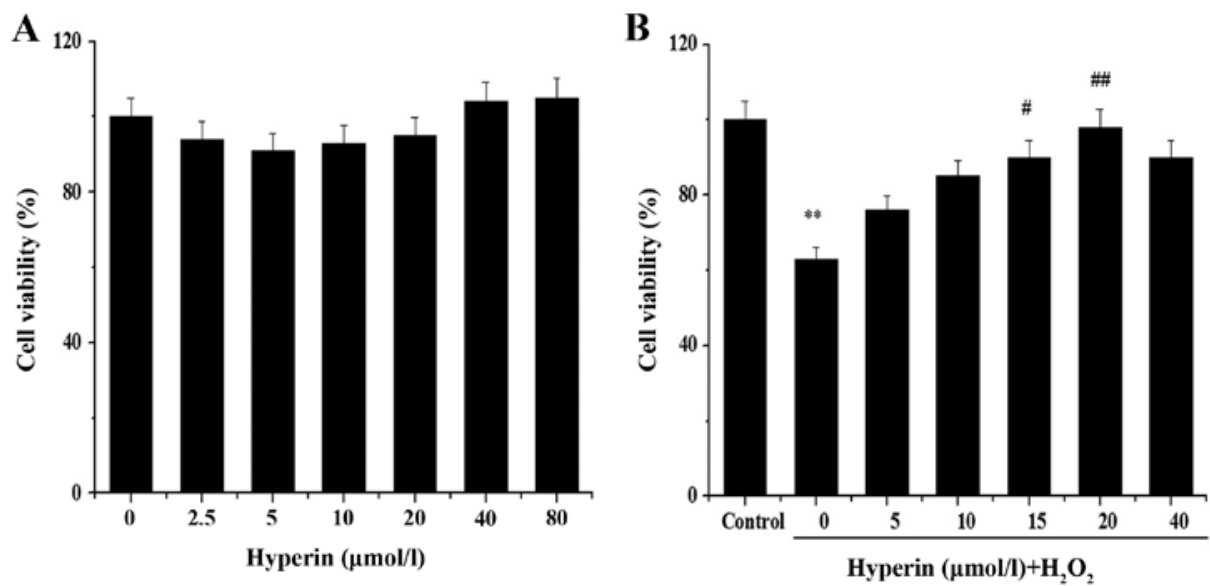

Figure 2. Cell viability determined by MTT assay. (A) EA.hy926 cells were incubated with increasing concentrations of hyperin (2.5-80 $\mu \mathrm{mol} / \mathrm{l})$ for $24 \mathrm{~h}$ to evaluate the cytotoxicity of hyperin. (B) EA.hy926 cells were treated with hyperin $(0-40 \mu \mathrm{mol} / \mathrm{l})$ for $24 \mathrm{~h}$ and then treated with $200 \mu \mathrm{mol} / 1 \mathrm{H}_{2} \mathrm{O}_{2}$ for $4 \mathrm{~h}$, and the cell viability of each group was measured. Data are presented as the means $\pm \mathrm{SD}(\mathrm{n}=6)$. ${ }^{* *} \mathrm{P}<0.01$ vs. control; ${ }^{\# \#} \mathrm{P}<0.01$ vs. $\mathrm{H}_{2} \mathrm{O}_{2}$ group; ${ }^{\#} \mathrm{P}<0.05$ vs. $\mathrm{H}_{2} \mathrm{O}_{2}$ group.

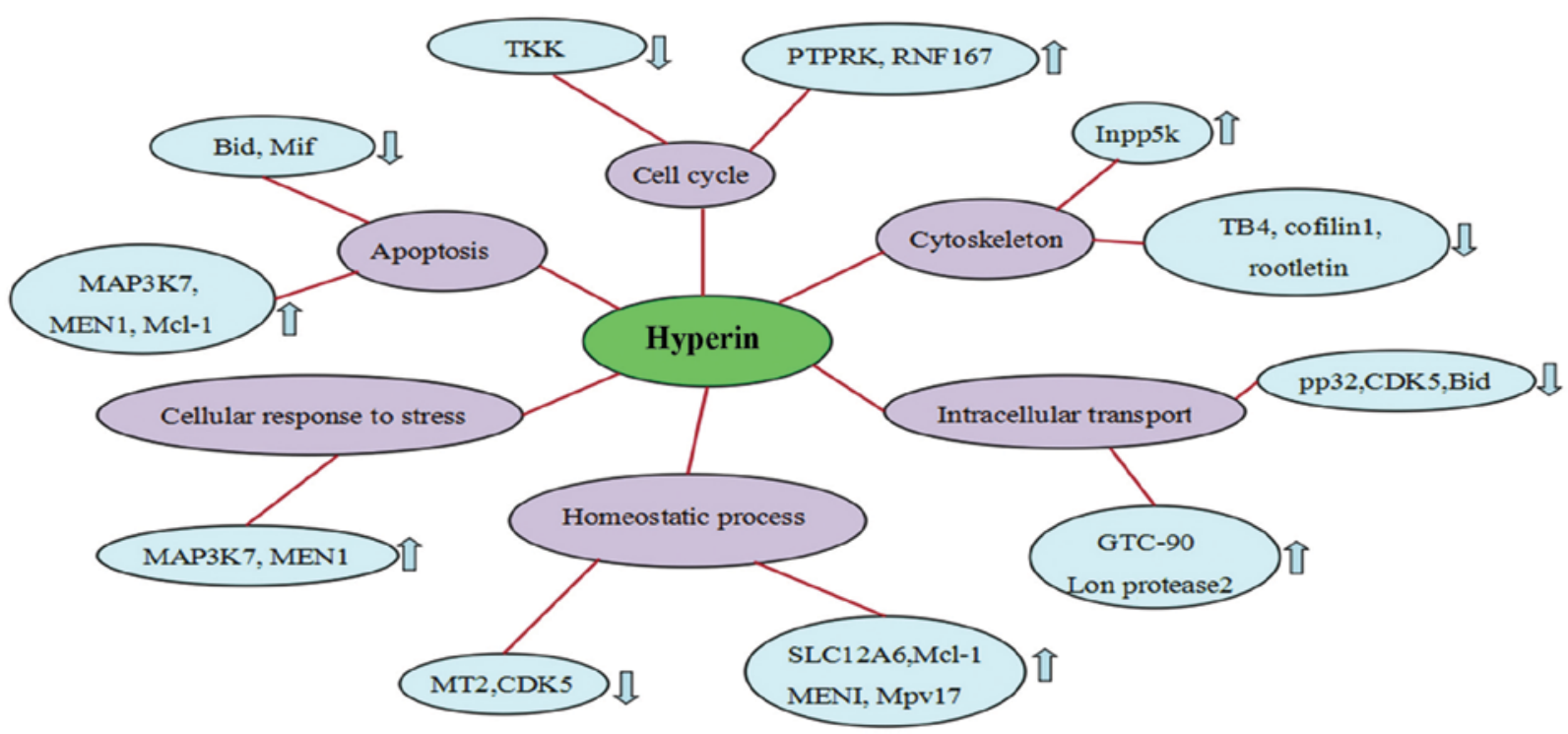

Figure 3. Schematic representation of the altered proteomic pathways in response to hyperin treatment. The altered proteins in the hyperin $+\mathrm{H}_{2} \mathrm{O}_{2}$ group are labeled with $(\downarrow)$ and $(\uparrow)$, representing the downregulated and upregulated proteins compared with the $\mathrm{H}_{2} \mathrm{O}_{2}$-exposed group.

A
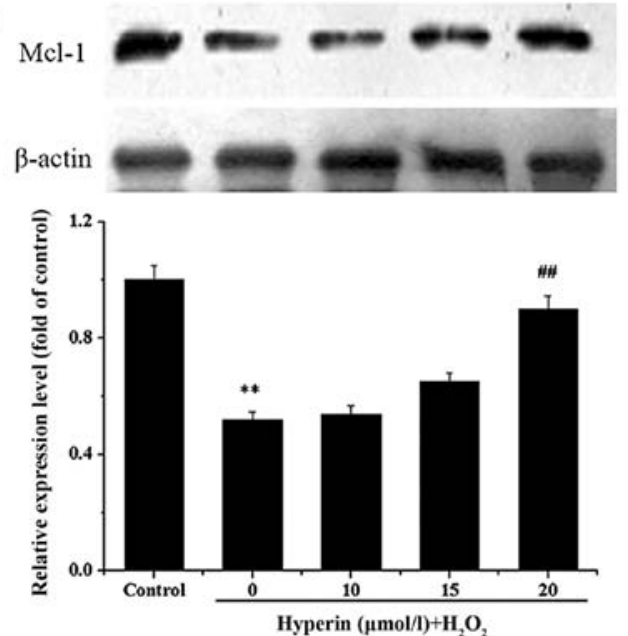

B

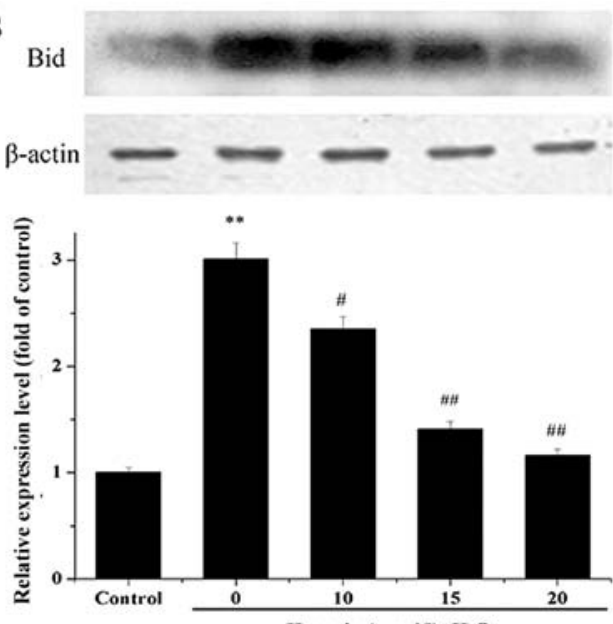

Hyperin $(\mu \mathrm{mol} / \mathrm{s})+\mathrm{H}_{2} \mathrm{O}_{2}$

Figure 4. Western blot analysis of the effects of hyperin on the expression of (A) myeloid cell leukemia sequence-1 (Mcl-1) and (B) BH3-interacting domain death agonist (Bid) in $\mathrm{H}_{2} \mathrm{O}_{2}$-exposed EA.hy926 cells. EA.hy926 cells were treated with hyperin for $24 \mathrm{~h}$ and then treated with $200 \mu \mathrm{mol} / 1 \mathrm{H}_{2} \mathrm{O}_{2}$ for $4 \mathrm{~h}$. Protein expression was normalized against that of $\beta$-actin. Data are presented as the means $\pm \mathrm{SD}(\mathrm{n}=3) .{ }^{* *} \mathrm{P}<0.01$ vs. control; ${ }^{\# \#} \mathrm{P}<0.01$ vs. $\mathrm{H}_{2} \mathrm{O}_{2}$ group; ${ }^{*} \mathrm{P}<0.05$ vs. $\mathrm{H}_{2} \mathrm{O}_{2}$ group. 

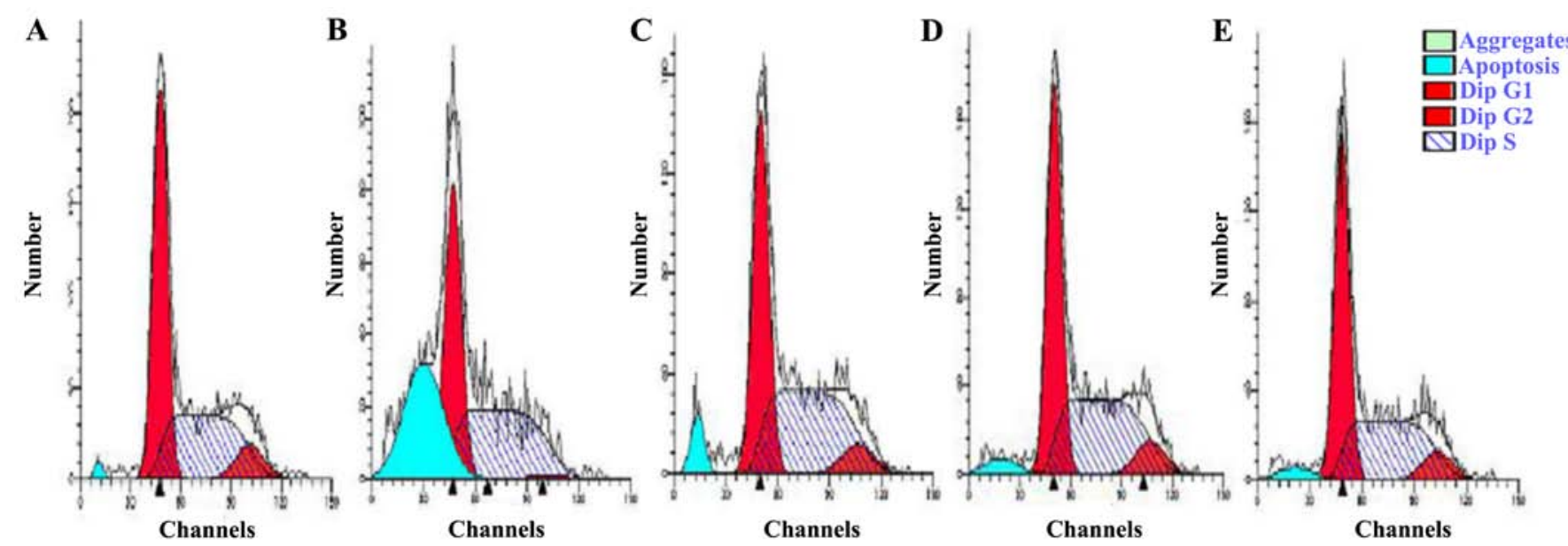

Figure 5. Apoptosis of EA.hy926 cells was measured by flow cytometry. (A) Control cells (no treatment). (B) Cells exposed to $200 \mu \mathrm{mol} / 1 \mathrm{H} \mathrm{O}_{2}$. (C-E) Cells treated with hyperin (10, 15 or $20 \mu \mathrm{mol} / 1$, respectively), prior to exposure to $200 \mu \mathrm{mol} / 1 \mathrm{H}_{2} \mathrm{O}_{2}$. Data are presented as the means $\pm \mathrm{SD}$ of triplicate values.

Hyperin protects EA.hy926 cells against $\mathrm{H}_{2} \mathrm{O}_{2}$-induced cell cycle arrest. We further analyzed the effect of $\mathrm{H}_{2} \mathrm{O}_{2}$ and hyperin on apoptosis and cell cycle distribution by flow cytometry. The group exposed to $200 \mu \mathrm{mol} / 1 \mathrm{H}_{2} \mathrm{O}_{2}$ exhibited a higher rate of apoptosis $(30.83 \%)$ than the control group (1.32\%) (Fig. 5). Treatment with hyperin at 10,15 or $20 \mu \mathrm{mol} / 1$ resulted in decreased accumulation of apoptotic cells at the sub-G peak compared with that in the $\mathrm{H}_{2} \mathrm{O}_{2}$-exposed group. The percentage of cells in the G0/G1 phase was increased in the $\mathrm{H}_{2} \mathrm{O}_{2}$-exposed group; however, it decreased in the hyperin group in a dose-independent manner. The results indicated that the cells were blocked in the G0/G1 phase following $\mathrm{H}_{2} \mathrm{O}_{2}$ treatment and that hyperin reduced the number of cells in cycle arrest, thereby reducing damage.

Expression of tBid, Fas, FasL, cleaved caspase-3, -8 and -9. Fas, FasL, cleaved caspase-3, -8, -9 play important roles in apoptosis. tBid is the cleaved form of Bid and is involved in the mitochondrial apoptotic pathway $(22,23)$. The expression of these proteins was assayed by western blot analysis to clarify the role of the Bid- and Mcl-1-mediated apoptosis mechanism in $\mathrm{H}_{2} \mathrm{O}_{2}$-injured EA.hy926 cells and the effect of hyperin. As shown in Fig. 6A-F, hyperin significantly decreased the relative expression of these proteins compared to that in the $\mathrm{H}_{2} \mathrm{O}_{2}$ group, in a dose-dependent manner.

\section{Discussion}

In our previous study (10), we found that hyperin exerted protective effects against $\mathrm{H}_{2} \mathrm{O}_{2}$-induced cell injury and cell cycle arrest, and decreased the accumulation of apoptotic cells at the sub-G peak, as was also demonstrated in the present study. In this study we aimed to further investigate the mode of action of hyperin using iTR AQ-based proteomic analysis. A total of 3,640 proteins were identified, of which 250 were found to be altered by $\mathrm{H}_{2} \mathrm{O}_{2}$; after treatment with hyperin, 52 of these proteins exhibited a tendency towards normal expression (see Table I). These proteins were associated with multiple biological processes including apoptosis, cell cycle, and cytoskeleton organization. The results of the MTT assay and flow cytometric analysis revealed that hyperin protects endothelial cells from cell apoptosis and death induced by $\mathrm{H}_{2} \mathrm{O}_{2}$. Therefore, we focused on the effect of hyperin on apoptosis. The functional roles of the proteins with altered expression levels following treatment with hyperin, which were found to be associated with apoptosis by iTRAQ analysis, are briefly discussed below.

In the present study, mitogen-activated protein kinase kinase kinase 7 (MAP3K7) and receptor-type tyrosine-protein phosphatase-kappa (PTPRK) expression was upregulated following hyperin treatment (Fig. 3), indicating that hyperin inhibits $\mathrm{H}_{2} \mathrm{O}_{2}$-induced apoptosis in the EA.hy926 cells. MAP3K7 acts as an essential component of the MAPK signal transduction pathway, which plays an important role in the oxidative stress response (13). Also, it is a crucial modulator of angiogenesis, and it has been demonstrated that MAP3K7 deletion is marked by TNF-dependent endothelial cell death and vessel regression (14). PTPRK regulates various processes, including cell growth, tumor invasion, cell cycle, and metastasis. Previous research has found that knockdown of PTPRK resulted in increased apoptosis through the c-Jun N-terminal kinase (JNK) pathway (15).

By contrast, the expression of macrophage migration inhibitory factor (Mif), and cofilin 1 (CFL1) in response to $\mathrm{H}_{2} \mathrm{O}_{2}$ was downregulated in hyperin-treated cells (Fig. 3). Mif is an inflammatory cytokine with chemokine-like functions, which has the capacity to induce apoptosis and cell dysfunction (16). Schumacher et al have reported that an increased level of Mif is associated with thrombosis (17), and that it plays a pivotal role in regulating platelet survival and thrombotic potential (18). CFL1 plays an important role in the regulation of cell morphology and cytoskeletal organization. A previous study has implied that mitochondrial translocation of CFL1 plays a crucial role in the promotion of apoptosis (19). Our findings suggested that the downregulation of Mif and CFL1 participates in the antithrombotic effect of hyperin. 
A

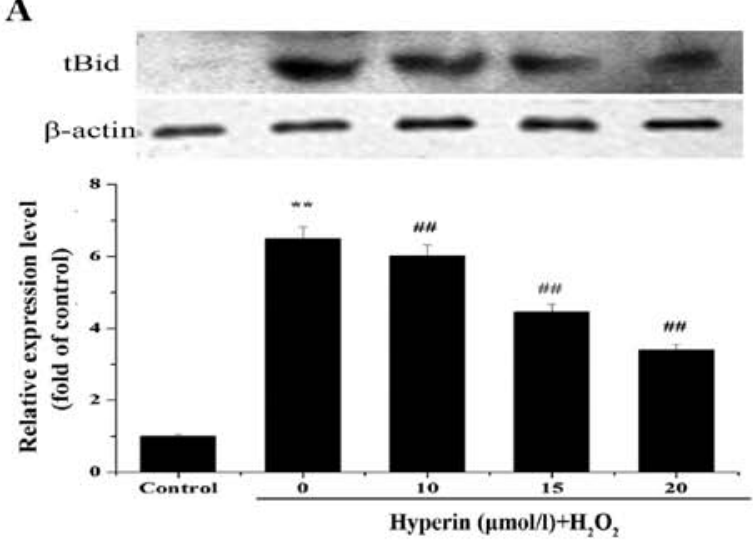

C

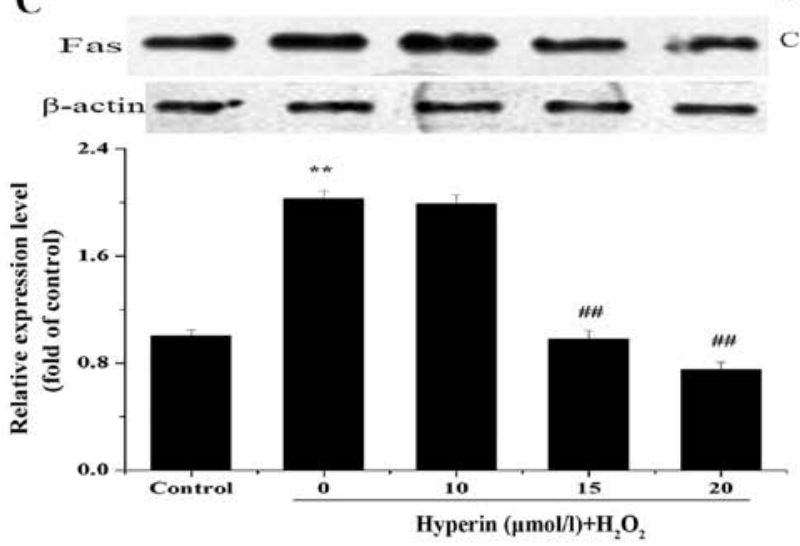

B

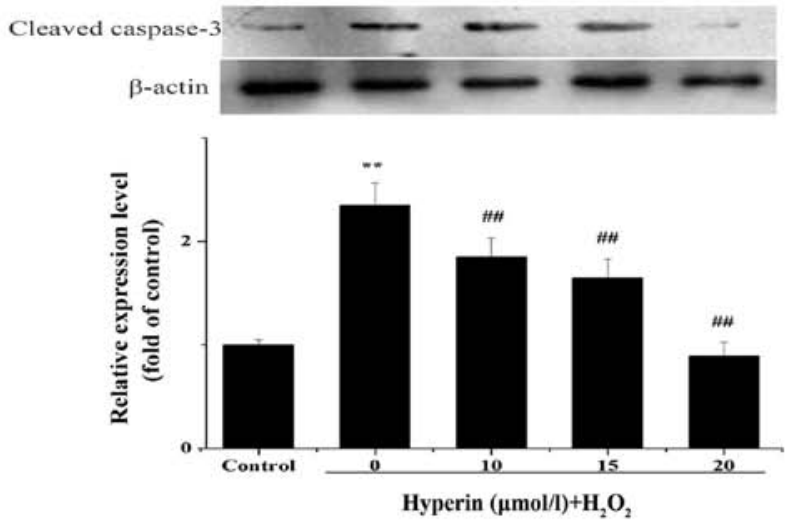

D
E

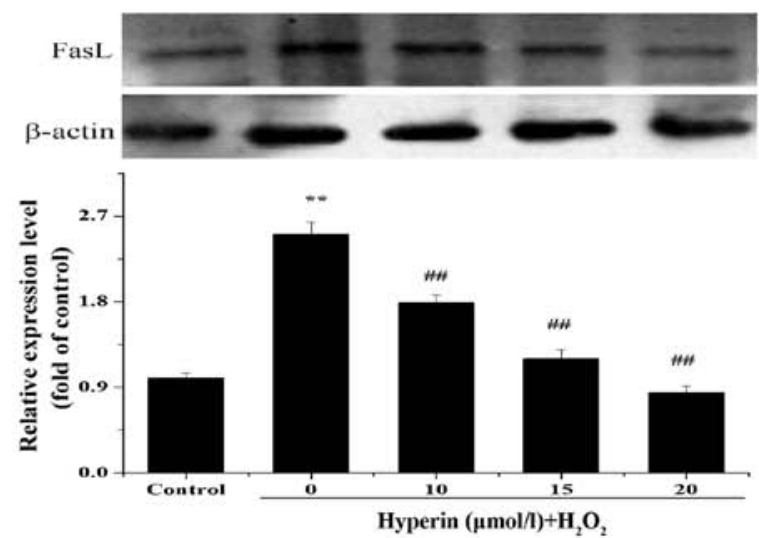

F
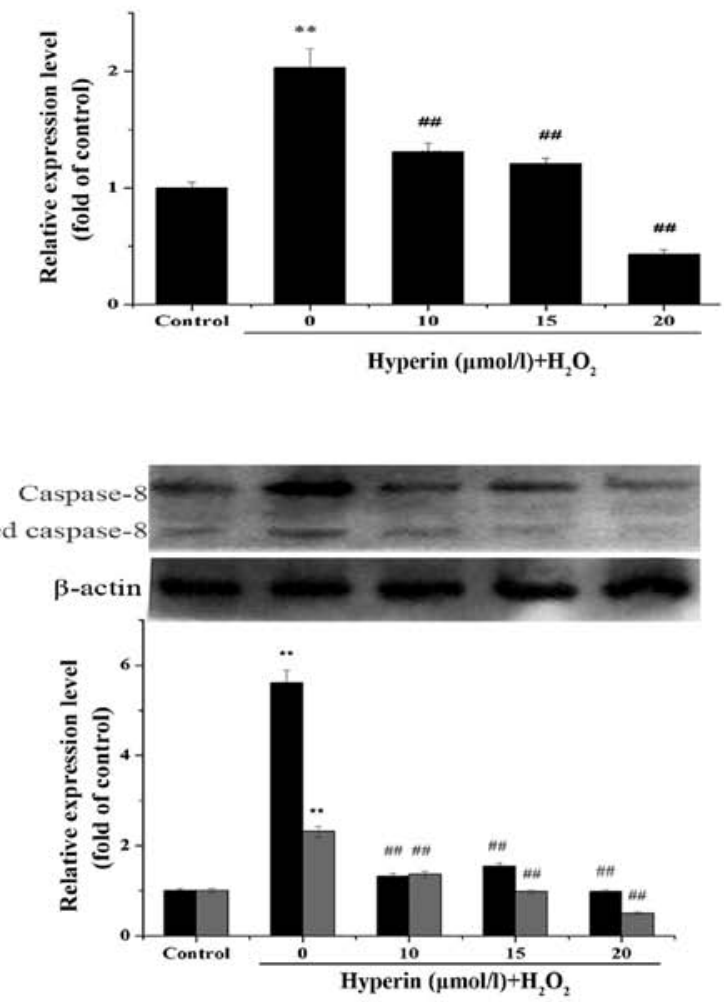

Figure 6. Western blot analysis of the effects of hyperin on expression of (A) tBid, (B) cleaved caspase-3, (C) Fas, (D) cleaved caspase-9, (E) FasL, (F) caspase-8 and cleaved caspase- 8 in $\mathrm{H}_{2} \mathrm{O}_{2}$-exposed EA.hy926 cells. EA.hy926 cells were treated with hyperin for $24 \mathrm{~h}$ and then exposed to $200 \mu$ mol/1 $\mathrm{H}_{2} \mathrm{O}_{2}$ for 4 h. Protein expression was normalized against that of $\beta$-actin. Data are represented as the means $\pm \mathrm{SD}(\mathrm{n}=3)$. ${ }^{* *} \mathrm{P}<0.01$ vs. control; ${ }^{\# \#} \mathrm{P}<0.01$ vs. $\mathrm{H}_{2} \mathrm{O}_{2}$ group.

iTRAQ proteomic analysis revealed marked changes in the expression of the anti-apoptotic protein, Mcl-1, and the pro-apoptotic protein, Bid. However, the mechanism underlying Bid- and Mcl-1-mediated apoptosis remains unclear and requires further study.

Mcl-1 is an outer mitochondrial membrane-bound protein of the Bcl-2 family that has a BH3-like domain, and plays an important role in the anti-apoptotic process (20). It has been shown to inhibit cell death by suppressing the release of cytochrome $c$ from the mitochondria, through binding and sequestering the pro-apoptotic proteins, Bak and Bax, on the outer mitochondrial membrane in EA.hy926 cells (21). By contrast, Bid is the only pro-apoptotic protein with a $\mathrm{BH} 3$ domain and is involved in the Fas and TNF signaling pathways (22). tBid is known to facilitate Bax translocation to the mitochondria, triggering the release of cytochrome $c$ from the mitochondria (23). In the present study, we found for the first time to the best of our knowledge, that hyperin induces an increase in the level of Mcl-1 and a decrease in Bid, in response to $\mathrm{H}_{2} \mathrm{O}_{2}$, in a dose-dependent manner. Furthermore, similar to Bid expression, the levels of the apoptosis-related proteins $\mathrm{tBid}$, Fas, FasL, cleaved caspase- $8,-9$ and -3 induced by $\mathrm{H}_{2} \mathrm{O}_{2}$ exposure were significantly decreased after treatment with hyperin. These data are in agreement with previous reseacrh which 
demonstrated that the apoptotic pathway is initiated by Fas and FasL, with sequential activation of the initiator caspase- 8 and Bid in the cells damaged by $\mathrm{H}_{2} \mathrm{O}_{2}$ (24). Bid is then cleaved into tBid, resulting in the release of cytochrome $c$ from mitochondria into the cytosol. Cytochrome $c$ binds to apoptotic protease activating factor-1 (Apaf-1) and then recruits caspase-9 to form the apoptosome complex. This complex results in the activation of caspase- 3 and execution of cell death (25). This process is regulated by anti-apoptotic proteins such as $\mathrm{Mcl}-1$ and $\mathrm{Bcl}-2$, and proapoptotic proteins such as tBid $(26,27)$. Our present findings indicated that hyperin blocks the Bid- and Mcl-1mediated apoptotic pathways that are involved in $\mathrm{H}_{2} \mathrm{O}_{2}$-induced apoptosis in EA.hy926 cells.

In conclusion, we systematically examined and compared the proteomic profiles of untreated, $\mathrm{H}_{2} \mathrm{O}_{2}$-exposed, and hyperin pre-treated EA.hy926 cells for the first time, to the best of our knowledge. The results demonstrate that hyperin effectively prevents $\mathrm{H}_{2} \mathrm{O}_{2}$-induced cell injury through regulation of the Mcl-1- and Bid-mediated anti-apoptotic mechanism. Our findings suggest that hyperin is a promising candidate for use in the treatment of thrombotic diseases.

\section{Acknowledgements}

This study was financially supported by the National Natural Science Foundation of China (grant nos. 81274132 and 81172938). We are grateful to Editage for providing editorial assistance.

\section{References}

1. Versari D, Daghini E, Virdis A, Ghiadoni L and Taddei S: Endothelial dysfunction as a target for prevention of cardiovascular disease. Diabetes Care 32 (Suppl 2): S314-S321, 2009.

2. Triggle CR, Samuel SM, Ravishankar S, Marei I, Arunachalam G and Ding H: The endothelium: influencing vascular smooth muscle in many ways. Can J Physiol Pharmacol 90: 713-738, 2012.

3. Choy JC, Granville DJ, Hunt DW and McManus BM: Endothelial cell apoptosis: biochemical characteristics and potential implications for atherosclerosis. J Mol Cell Cardiol 33: 1673-1690, 2001

4. Aird WC: Endothelium and haemostasis. Hamostaseologie 35: 11-16, 2015.

5. Middleton E Jr, Kandaswami C and Theoharides TC: The effects of plant flavonoids on mammalian cells: implications for inflammation, heart disease, and cancer. Pharmacol Rev 52: 673-751, 2000.

6. Wang WQ, Ma CG and Xu SY: Protective effect of hyperin against myocardial ischemia and reperfusion apoptosis. Acta Pharmacol Sin 17: 341-344, 1996.

7. Bernatoniene J, Trumbeckaite S, Majiene D, Baniene R, Baliutyte G, Savickas A and Toleikis A: The effect of crataegus fruit extract and some of its flavonoids on mitochondrial oxidative phosphorylation in the heart. Phytother Res 23: 1701-1707, 2009.

8. Li ZL, Liu JC, Hu J, Li XQ, Wang SW, Yi DH and Zhao MG: Protective effects of hyperoside against human umbilical vein endothelial cell damage induced by hydrogen peroxide. J Ethnopharmacol 139: 388-394, 2012.

9. Müller WE, Singer A, Wonnemann M, Hafner U, Rolli M and Schäfer C: Hyperforin represents the neurotransmitter reuptake inhibiting constituent of hypericum extract. Pharmacopsychiatry 31 (Suppl 1): 16-21, 1998.

10. Hao XL: Study on the substance bases of anti-thrombi activity and the mechanism of anti-apoptosis of human umbilical vein endothelial cells of total flavonoids from Folium Apocyni Veneti. Ph.D thesis, Shanxi Medical University, 2009 (In Chinese).
11. Ross PL, Huang YN, Marchese JN, Williamson B, Parker K, Hattan S, Khainovski N, Pillai S, Dey S, Daniels S, et al: Multiplexed protein quantitation in Saccharomyces cerevisiae using amine-reactive isobaric tagging reagents. Mol Cell Proteomics 3: 1154-1169, 2004

12. Aggarwal K, Choe LH and Lee KH: Shotgun proteomics using the iTRAQ isobaric tags. Brief Funct Genomics Proteomics 5: 112-120, 2006.

13. Lim D, Roh JY, Eom HJ, Choi JY, Hyun J and Choi J: Oxidative stress-related PMK-1 P38 MAPK activation as a mechanism for toxicity of silver nanoparticles to reproduction in the nematode Caenorhabditis elegans. Environ Toxicol Chem 31: 585-592, 2012.

14. Morioka S, Inagaki M, Komatsu Y, Mishina Y, Matsumoto K and Ninomiya-Tsuji J: TAK1 kinase signaling regulates embryonic angiogenesis by modulating endothelial cell survival and migration. Blood 120: 3846-3857, 2012.

15. Sun PH, Ye L, Mason MD and Jiang WG: Receptor-like protein tyrosine phosphatase $\kappa$ negatively regulates the apoptosis of prostate cancer cells via the JNK pathway. Int J Oncol 43: 1560-1568, 2013.

16. Stojanovic I, Saksida T, Timotijevic G, Sandler S and Stosic-Grujicic S: Macrophage migration inhibitory factor (MIF) enhances palmitic acid- and glucose-induced murine beta cell dysfunction and destruction in vitro. Growth Factors 30: 385-393, 2012.

17. Schumacher E, Vigh E, Molnár V, Kenyeres P, Fehér G, Késmárky G, Tóth K and Garai J: Thrombosis preventive potential of chicory coffee consumption: a clinical study. Phytother Res 25: 744-748, 2011

18. Chatterjee M, Borst O, Walker B, Fotinos A, Vogel S, Seizer P, Mack A, Alampour-Rajabi S, Rath D, Geisler T, et al: Macrophage migration inhibitory factor limits activation-induced apoptosis of platelets via CXCR7-dependent Akt signaling. Circ Res 115: 939-949, 2014.

19. Tang Q, Ji Q, Tang Y, Chen T, Pan G, Hu S, Bao Y, Peng W and Yin P: Mitochondrial translocation of cofilin-1 promotes apoptosis of gastric cancer BGC-823 cells induced by ursolic acid. Tumour Biol 35: 2451-2459, 2014.

20. Yang T, Kozopas KM and Craig RW: The intracellular distribution and pattern of expression of Mcl-1 overlap with, but are not identical to, those of Bcl-2. J Cell Biol 128: 1173-1184, 1995.

21. Shimazu T, Degenhardt K, Nur-E-Kamal A, Zhang J, Yoshida T, Zhang $Y$, Mathew $R$, White $E$ and Inouye $M$ : NBK/BIK antagonizes MCL-1 and BCL-XL and activates BAK-mediated apoptosis in response to protein synthesis inhibition. Genes Dev 21: 929-941, 2007.

22. Luo X, Budihardjo I, Zou H, Slaughter C and Wang X: Bid, a $\mathrm{Bcl} 2$ interacting protein, mediates cytochrome $c$ release from mitochondria in response to activation of cell surface death receptors. Cell 94: 481-490, 1998.

23. Li H, Zhu H, Xu CJ and Yuan J: Cleavage of BID by caspase 8 mediates the mitochondrial damage in the Fas pathway of apoptosis. Cell 94: 491-501, 1998.

24. Inagaki M, Omori E, Kim JY, Komatsu Y, Scott G, Ray MK, Yamada G, Matsumoto K, Mishina Y and Ninomiya-Tsuji J: TAK1-binding protein 1, TAB1, mediates osmotic stress-induced TAK1 activation but is dispensable for TAK1-mediated cytokine signaling. J Biol Chem 283: 33080-33086, 2008.

25. Chun KH, Benbrook DM, Berlin KD, Hong WK and Lotan R: The synthetic heteroarotinoid SHetA2 induces apoptosis in squamous carcinoma cells through a receptor-independent and mitochondria-dependent pathway. Cancer Res 63: 3826-3832, 2003.

26. Gogvadze V, Orrenius S and Zhivotovsky B: Multiple pathways of cytochrome $c$ release from mitochondria in apoptosis. Biochim Biophys Acta 1757: 639-647, 2006.

27. Yin XM: Signal transduction mediated by Bid, a pro-death Bcl-2 family proteins, connects the death receptor and mitochondria apoptosis pathways. Cell Res 10: 161-167, 2000. 